\title{
Application of dried plant biomass as novel low-cost adsorbent for removal of cadmium from aqueous solution
}

\author{
A. Dubey $\cdot$ A. Mishra $\cdot$ S. Singhal
}

Received: 31 December 2011/Revised: 3 June 2012/Accepted: 16 March 2013/Published online: 16 April 2013

(C) Islamic Azad University (IAU) 2013

\begin{abstract}
Heavy metals are a threat to human health and ecosystem. These days, great deal of attention is being given to green technologies for purification of water contaminated with heavy metal ions. Biosorption is one among such emerging technologies, which utilizes naturally occurring waste materials to sequester heavy metals from wastewater. Cadmium has hazardous impact on living beings; therefore, its removal through green and economical process is an important task. The aim of the present study was to utilize the locally available Portulaca oleracea plant biomass as an adsorbent for cadmium removal from aqueous solution. The biomass was obtained after drying and grinding the portulaca leaves and stem. No chemical treatment was done on the adsorbent so that it remained green in a true sense. Batch experiments were performed at room temperature. The critical parameters studied were effects of $\mathrm{pH}$, contact time, initial metal ion concentration and adsorbent dose on the adsorption of cadmium. The maximum adsorption was found to be $72 \%$. The kinetic data were found to best fit the pseudo-secondorder equation. High adsorption rates were obtained in the initial $45 \mathrm{~min}$, and adsorption equilibrium was then
\end{abstract}

\footnotetext{
A. Dubey $(\square)$

Department of Chemistry, MMH College, Affiliated to CCS

University Meerut, Ghaziabad 201009, India

e-mail: abhaadubey@gmail.com
}

A. Mishra

Department of Applied Chemistry, School of Vocational Studies and Applied Sciences, Gautam Buddha University,

Gautam Budh Nagar 201 308, India

S. Singhal

Department of Applied Sciences, AKG Engineering College, Affiliated to Mahamaya Technical University Noida,

Ghaziabad 201009, India gradually achieved in about 100 min. Adsorption increased with increase in $\mathrm{pH}$ for a range 2 and 6 . The equilibrium adsorption results closely followed both the Langmuir and Freundlich isotherms. The values of constants were calculated from isotherms. Results indicated that portulaca plant biomass could be developed as a potential material to be used in green water treatment devices for removal of metal ions.

Keywords Batch experiment - Isotherms - Portulaca oleracea $\cdot$ Pseudo-second-order equation

\section{Introduction}

Water pollution due to toxic heavy metals has been a major concern for scientists. Metals can be distinguished from other toxic pollutants, since they are non-biodegradable, and can be concentrated and accumulated throughout the food chain and tissues. A variety of industries are responsible for the release of heavy metals into the environment through their effluents.

Cadmium $[\mathrm{Cd}(\mathrm{II})]$ is a non-essential and a non-biodegradable metal ion which slowly accumulates in the body of living creatures, usually through food chain. It is one of the metals with the greatest potential hazard (Akar and Tunali 2006). Cadmium enters in the water bodies through wastes generated from industrial processes such as casting of various cadmium alloy products, coating telephone cables, ceramics, metal electroplating, plastic manufacturing, metallurgical processes, industries of pigments and $\mathrm{Cd} / \mathrm{Ni}$ batteries (Volesky 1992; Cheremisinoff 1995). Cadmium is also found in domestic products like tobacco products, phosphate fertilizer, polyvinyl chloride (PVC) products, photo cells, petrol, oils, etc. (Sitting 1991). 
Due to the toxicity and bioaccumulation of heavy metals various governmental agencies have imposed strict environmental legislations on waste water discharge. Government of India, has set Minimal National Standards (MINAS 2001) of $0.2 \mathrm{mg} / \mathrm{l}$ for Cd(II) for safe discharge of the effluents containing this metal ion into surface waters. $\mathrm{Cd}(\mathrm{II})$ is considered as a priority pollutant by the US Environmental Protection Agency. Environmental agencies set permissible limits for their respective levels in drinking water and other types of waters (Vander Leeden et al. 1990). The permissible limit for Cd(II) as described by WHO is $0.005 \mathrm{mg} / \mathrm{l}$ (WHO 1971). This value is considered as the threshold for the protection of public health.

Cadmium $(\mathrm{Cd})$ is extremely toxic in relatively low dose (Xiong et al. 2009). It is an irritant to the respiratory tract. The harmful effects of cadmium include number of acute and chronic disorders (Cheremisinoff 1995). "Itai-Itai" disease in Japan due to cadmium toxicity is well known. Cadmium is also responsible for kidney damage, renal disorder, high blood pressure, destruction of red blood cells (Drash 1993), pulmonary emphysema, hypertension (Cay et al. 2004) and bone diseases (osteomalacia, osteoporosis) (Thun et al. 1985). Prolonged exposure to this pollutant can cause anemia and a yellow stain that gradually appears on the joints of the teeth.

There are several methods to treat the contaminated water; the selection of the treatment methods is based on the level of the waste and the cost of treatment (Ajmal et al. 2003). Conventional methods for the removal of the heavy metal ions from wastewaters include chemical precipitation, electro flotation, ion exchange, reverse osmosis and adsorption onto activated carbon. These methods have been found to be limited, since they often involve high capital and operational costs, incomplete removal (Brown et al. 2000), and may be associated with the generation of secondary waste which is again to be treated or to be safely disposed off (Chandra et al. 2003).

Adsorption is very economical and effective process (Park et al. 2007; Dubey and Shiwani 2012). Adsorption has advantages over the other methods because of its simple design with a sludge-free environment and can involve low investment in terms of both initial cost and land required. Activated carbon has been recognized as a highly effective adsorbent for the removal of heavy metal ion from the concentrated and dilute metal-bearing effluents (Netzer and Hughes 1984; Reed et al. 1994). The high cost of activated carbon has prompted a search for cheaper substitutes. Many studies are recently devoted to use different adsorbent materials in processes involving the removal of $\mathrm{Cd}(\mathrm{II})$ ions from aqueous effluents with the aim of finding cheaper replacements for expensive conventional sorbent materials in different situations.
Natural materials that are available in large quantities and certain wastes from agricultural operations have potential to be used as low-cost adsorbents, as they represent unused resources, widely available and are environmentally friendly (Deans and Dixon 1992). Many investigators have used inexpensive sorbent materials such as cassava waste (Horsfall and Abia 2003), waste material (Ulmanu et al. 2003), rice polish, and waste tea (Alhluwalia and Goyal 2005).

The efficiency of some plant materials to remove metals, which commonly occur in industrial effluents, has been studied. Among many adsorbents naturally available plant biomass can be used as an inexpensive method for metal ions removal from synthetic solutions and industrial effluents (Manal 2007) olive cake (Al-Anber and Matouq 2008), barley straw (Pehlivan et al. 2009), Typha leaf powder (Abdel-Ghani et al. 2009), neem bark (Naiya et al. 2009), mangosteen (Zein et al. 2010) coffee ground (Azouaoua et al. 2010), peanut shell (Witek-Krowiak et al. 2011) plant material (Dubey and Shiwani 2012) has been used for such removals. The effects of factors such as contact time, $\mathrm{pH}$ and initial metal ion concentration were investigated (Babarinde et al. 2007; Akar and Tunali 2006; Sawalha et al. 2006; Wang and Chen 2006).

Present work deals with the evaluation of efficiency of portulaca plant biomass (PPBM), obtained from its leaves and stems, as adsorbent for $\mathrm{Cd}(\mathrm{II})$ ions removal from water samples. The plant was easily available and therefore used as a low-cost adsorbent in this study. This adsorbent, as a natural organic matter obtained from dried plant and used without any chemical treatment, is completely chemical free, green and environmental friendly. It has great potential to be used as adsorbent for heavy metals. Batch experiments were done to study the effects of variables such as contact time, $\mathrm{pH}$, initial metal ion concentration and PPBM dose on $\mathrm{Cd}(\mathrm{II})$ removal. The applicability of different isotherm equations were tested by the data obtained and kinetics of adsorption was also studied. Process used in the present study is rather simple, cost-effective and easy to extrapolate at larger scale for a practical application of the removal of heavy metal ions.

This work was done at MMH College, Ghaziabad, India, and was completed in August 2011.

\section{Materials and methods}

\section{Adsorbent}

Portulaca plant biomass (PPBM) is used in the present study. Portulaca olerecea is a herbaceous weed. Phytochemical screening of plant revealed the presences of many biologically active compounds such as alkaloids, 
carbohydrates, flavonoids, amino acids, proteins, steroids, saponins, fixed oils, tannins and phenolic compounds (Kokate 1986; Harbone 1998). Due to the presence of many functional groups, this plant material can be used as good adsorbent for removal of cations and anions from aqueous solutions.

Portulaca plant was collected from the local gardens. The collected material was washed several times by tap water to remove all the dirt and any other extraneous depositions. This material was again thoroughly washed with double distilled water. Material was sun dried for 10 days, and then in microwave for about $30 \mathrm{~min}$ in a LG make domestic microwave oven having temperature range $40-100{ }^{\circ} \mathrm{C}$ (magnetrons are set at a frequency of 2,450 MHz) (LG microwave appliance model no. MS285SD; Korea). This dried material was then ground and sieved to uniform size particles $(\sim 355 \mu \mathrm{m})$. No other chemical treatment was done. Powdered material (PPBM) was kept in air tight containers and used when required.

\section{Adsorbate}

All the chemicals used in experiments were of analytical grade. A stock solution was prepared by dissolving 1,000 mg of cadmium nitrate (Merck) in one liter of double distilled water. The stock solution was diluted and used for different concentrations of cadmium ions required for the experiments.

\section{Batch adsorption studies}

Batch adsorption studies were carried out by adding a known weight of PPBM to a $200 \mathrm{ml}$ solution of metal ion under different test conditions. The uptake capacity of $\mathrm{Cd}(\mathrm{II})$ was studied. The effect of solution $\mathrm{pH}$, contact time, initial metal ion concentration, and dose of PPBM were studied by varying any one of the process parameter and keeping the other parameters constant. The adsorption experiments of $\mathrm{Cd}$ (II) were conducted at $27^{\circ} \mathrm{C}$ in a thermostated water bath shaker at $100 \mathrm{rpm}$ speed. The adsorbent was separated from the solution by filtration with Whatman filter paper number 41 followed by centrifugation at 3,000 rpm for $10 \mathrm{~min}$. The residual metal ions were analyzed using an atomic adsorption spectrophotometer (GBC Avanta). Adsorption data obtained were applied for testing the applicability of different isotherms equations. Blank samples were also run under similar conditions. Each of the studies was conducted in triplicates and the mean value was used for calculations.

\section{Kinetics experiments}

Cd(II) ions solution with a concentration of 500 ppm was taken for the study. The initial $\mathrm{pH}$ of the solution was adjusted to 6. An accurately weighed amount of PPBM $(1.5 \mathrm{~g})$ was added and the flask was agitated in the thermostated water bath. The temperature of the solution was kept constant at $27{ }^{\circ} \mathrm{C}$. Samples were withdrawn from the solution at definite time intervals until equilibrium was reached. The residual metal ion concentration was calculated as mentioned earlier. Data obtained were applied to different kinetic equations.

\section{Results and discussion}

\section{Effect of $\mathrm{pH}$}

$\mathrm{pH}$ governs both the speciation of metals and the dissociation of active functional sites on the adsorbent (Azouaoua et al. 2010). It is one of the most important factor affecting metal adsorption onto adsorbent, as hydrogen ions compete with the adsorbate (Prasanna Kumar et al. 2007). Studies were conducted by keeping the metal ion concentration constant at $500 \mathrm{ppm}$ and varying the amount of adsorbent (PPBM) from 0.25 to $1.5 \mathrm{~g}$. The $\mathrm{pH}$ of each of the solutions was adjusted to the desired value by adding $0.1 \mathrm{M} \mathrm{HCl}$ or $0.1 \mathrm{M} \mathrm{NaOH}$ solution. The effect of $\mathrm{pH}$ (range 2-7) on adsorption of $\mathrm{Cd}(\mathrm{II})$ ions is shown in Fig. 1. Adsorption
Fig. 1 Effect of $\mathrm{pH}$ on adsorption

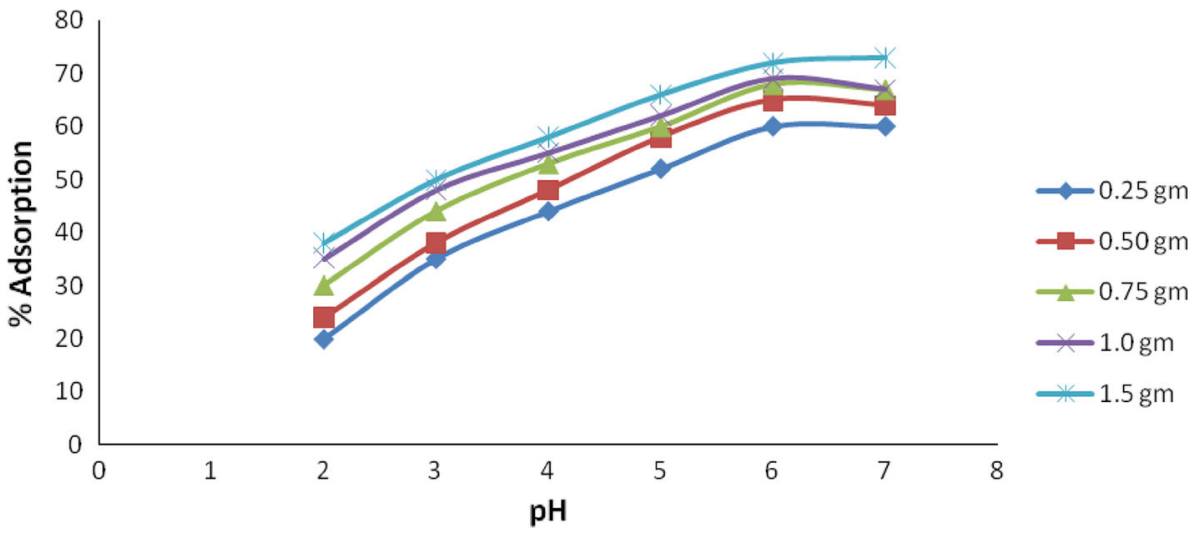


Fig. 2 Effect of contact time on adsorption

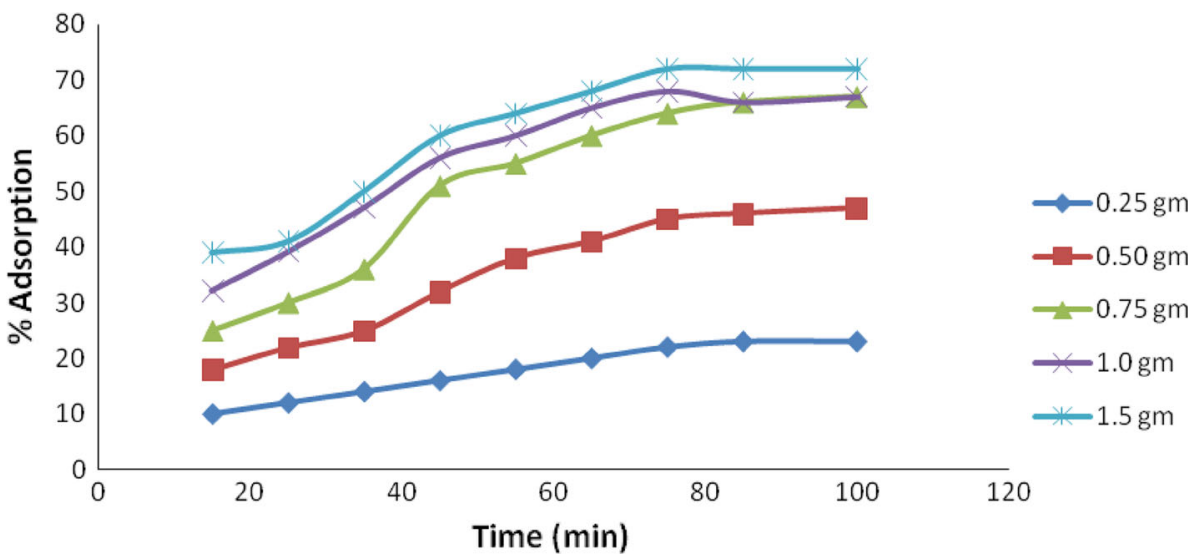

increased with increase in $\mathrm{pH}$ until it reached a maximum at $\mathrm{pH} 6$.

It may be due to the fact that active adsorption sites remain protonated at low $\mathrm{pH}$, and become less available for metal ion adsorption. As $\mathrm{pH}$ increases, the concentration of $\mathrm{H}^{+}$ions decreases, hence they do not compete with metal ions on the adsorption sites, the more adsorbent surface with negative charge will easily attract the positively charged Cd(II) ions (Brady and Duncan 1994). Optimum $\mathrm{pH}$ was found to be 6 for further experiments. At higher $\mathrm{pH}$ cadmium hydroxide starts precipitating from the solution, making actual adsorption studies impossible (Ajmal et al. 2003). This result confirms the earlier report that the adsorption is pH-dependent (Pavasant et al. 2006).

\section{Effect of contact time}

Contact time is an important factor for economical adsorption. The adsorption of $\mathrm{Cd}(\mathrm{II})$ ions was studied as a function of time (15-100 $\mathrm{min})$. Test solution was prepared by keeping the $\mathrm{Cd}(\mathrm{II})$ ion concentration constant (500 ppm) and varying the adsorbent dose (PPBM) from 0.25 to $1.5 \mathrm{~g}$. The $\mathrm{pH}$ of the solution adjusted to optimum $\mathrm{pH}$ value obtained from experimental data, i.e., 6. The results are shown in Fig. 2. It is observed from the figure that the percentage adsorption of $\mathrm{Cd}$ (II) ion increased with increase in contact time. Initially adsorption was rapid; it may be due to more active binding sites present on the adsorbent in the beginning. It became slower after some time; it might be due to lesser number of available active binding sites on the adsorbent. The adsorption reached equilibrium within $100 \mathrm{~min}$. This period of $100 \mathrm{~min}$ was therefore used for the other adsorption experiments.

The adsorption of metal ions has been reported to be biphasic (Liu et al. 2006). The initial fast phase occurs due to surface adsorption on the adsorbent. This might be due to availability of higher number of active adsorption sites on the surface of adsorbent. Adsorption became slower in the second phase because of lesser number of available active sites; adsorbate was transported from the outer surface to the inner surface of the adsorbent particles. It is observed in Fig. 2 that the metal adsorption rate is high initially, with maximum adsorption in $100 \mathrm{~min}$. The results are consistent with studies reported earlier (Low et al. 2000).

The optimum operating conditions for batch process can be generated from the information on the kinetics. The adsorption rate was observed to be very high initially and thereafter the reaction proceeds at a slower rate until $100 \mathrm{~min}$ and then it almost stayed constant.

Kinetic modeling

We attempted to analyze the adsorption data using pseudofirst-order and pseudo-second-order kinetic models. Lagergren pseudo-first-order model assumes that the rate of occupation of sorption sites is proportional to the number of unoccupied sites (Cruz et al. 2004), i.e., rate of change of solute uptake with time is directly proportional to the difference in the saturation concentration and the amount of solid uptake with time. The general form of this model is expressed as

$\frac{\mathrm{d} q_{t}}{\mathrm{~d} t}=k_{1}\left(q_{\mathrm{e}}-q_{t}\right)$

$q_{\mathrm{e}}$ and $q_{t}$ are amount of adsorbate $(\mathrm{mg} / \mathrm{g})$ at time $t$ and at equilibrium, respectively. $k_{1}$ is the rate constant of pseudofirst-order adsorption. Integrated form of equation is

$\frac{q_{t}}{q_{\mathrm{e}}}=1-e^{\left(-k_{1} t\right)}$ or $\log \left(q_{\mathrm{e}}-q_{t}\right)=\log q_{\mathrm{e}}-\frac{k_{1} t}{2.303}$.

Linear plot of $\log \left(q_{\mathrm{e}}-q_{t}\right)$ versus $t$ shows the applicability of pseudo-first-order kinetic model (Lagergren and Vetenskapsakad 1898; McKay 1996; Ho and McKay 1999). The rate constant $k_{1}$ and equilibrium amount of metal ion $q_{\mathrm{e}}$ can be obtained from the slope and the intercept of plot (Fig. 3). Correlation coefficient for the pseudo-first-order was 0.955 . The calculated value of $k_{1}$ and $q_{\mathrm{e}}$ was $0.05 \mathrm{~min}^{-1}$ and $73.11 \mathrm{mg} \mathrm{g}^{-1}$, respectively. 


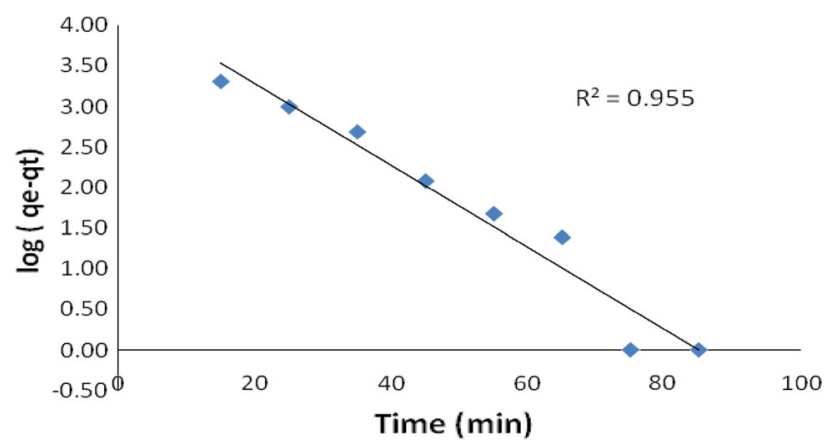

Fig. 3 Pseudo-first-order kinetics plots for the adsorption

The pseudo-second-order model (Ho and McKay 1999) is based on sorption capacity of solid phase.

$\frac{\mathrm{d} q_{t}}{\mathrm{~d} t}=k_{2}\left(q_{\mathrm{e}}-q_{t}\right)^{2}$

where $k_{2}$ is rate constant of pseudo-second-order adsorption $\left(\mathrm{g} \mathrm{mg}^{-1} \mathrm{~min}^{-1}\right)$. Integrated linear form of equation is

$\frac{t}{q_{t}}=\frac{1}{k_{2} q_{\mathrm{e}}^{2}}+\frac{t}{q_{\mathrm{e}}}$.

This is the linear form of Ho second-order model. The plot of $t / q_{t}$ versus $t$ (Fig. 4) shows the kinetic data of adsorption of cadmium ions on the adsorbent. The good fit of kinetic data in second-order rate expression shows excellent linearity with high correlation coefficient $R^{2}$. The rate constant $k_{2}$ and equilibrium amount of metal ion $q_{\mathrm{e}}$ can be obtained from the slope and the intercept of plot (Fig. 4).

The value of $k_{2}, q_{\mathrm{e}}$ was calculated as 0.0004 $\left(\mathrm{g} \mathrm{mg}^{-1} \mathrm{~min}^{-1}\right), 71.4286\left(\mathrm{mg} \mathrm{g}^{-1}\right)$. The correlation coefficient for the pseudo-second-order was 0.991. The kinetic plots of $t / q_{t}$ versus $t$ at different metal ion concentrations are presented in Fig. 4 which shows relationship is linear; and high value of correlation coefficient explains that the process follows the pseudo-second-order model in comparison to pseudo-first-order model.

Effect of adsorbent dose and initial cadmium ion concentration

Adsorbent dose has a significant influence on the adsorption, as it determines the capacity of an adsorbent for a given initial concentration of the adsorbate at the given operating conditions. Batch adsorption study was carried out using $200 \mathrm{ml}$ aqueous solution of cadmium ions (concentration range of $100-500 \mathrm{mg} / \mathrm{l}$ ). PPBM doses range from 0.25 to $1.5 \mathrm{~g}$ at $\mathrm{pH} 6$ for each concentration of metal ions studied at $27{ }^{\circ} \mathrm{C}$ for $100 \mathrm{~min}$. Percentage removal of $\mathrm{Cd}(\mathrm{II})$ ions for different sets is shown in Fig. 5.

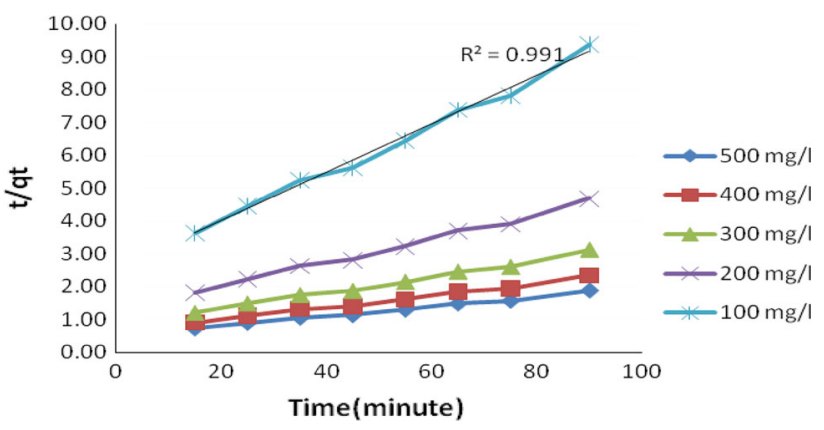

Fig. 4 Pseudo-second-order kinetics plots for adsorption at different cadmium ion concentration

It is clear from the data obtained as shown in Fig. 5 that the removal efficiency is generally improved with the increasing amount of adsorbent. As adsorbent dose is increased more surface area is available for adsorption due to increase in active sites on the adsorbent. Our results showed that the maximum removal was obtained for $1.5 \mathrm{~g}$ of adsorbent in all the experiments, which is used as optimum dose for all other experiments.

As shown in the Fig. 5, the change of initial metal ion concentration has a significant effect on adsorption. The effect of initial $\mathrm{Cd}(\mathrm{II})$ concentration on the adsorption capacity shows that maximum $72 \%$ of the metal ion was adsorbed at the initial metal ion concentration of $500 \mathrm{mg} / \mathrm{l}$.

Initially the adsorption increases as the initial metal ion concentration increases after that it became constant. Results indicate that as the initial Cd(II) ions is increased, metal ion intake tends to saturate. Similar trend has been reported by many other workers (Brown et al. 2001; Al-Subu 2002). The gradual increase in the efficiency of the adsorbent with the increase of metal ion concentration shows the saturation of the available binding sites.

Equilibrium modeling

An adsorption isotherm is characterized by certain constants; their values express the surface properties and

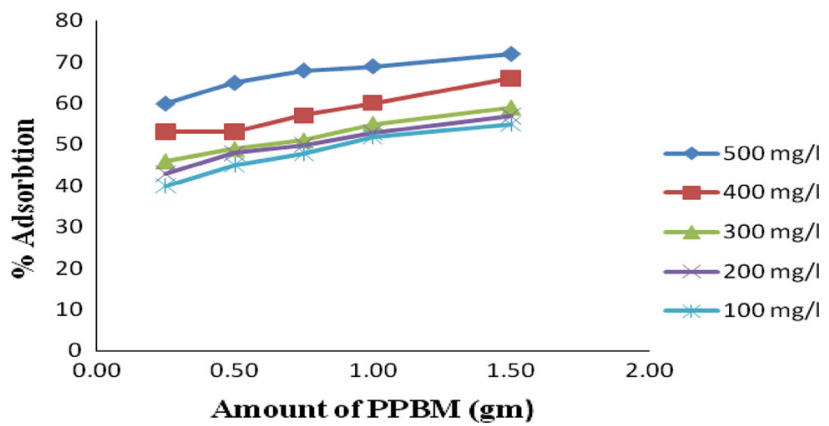

Fig. 5 Effect of adsorbent dose (at different metal ion concentration $\mathrm{mg} / \mathrm{l})$ on adsorption 


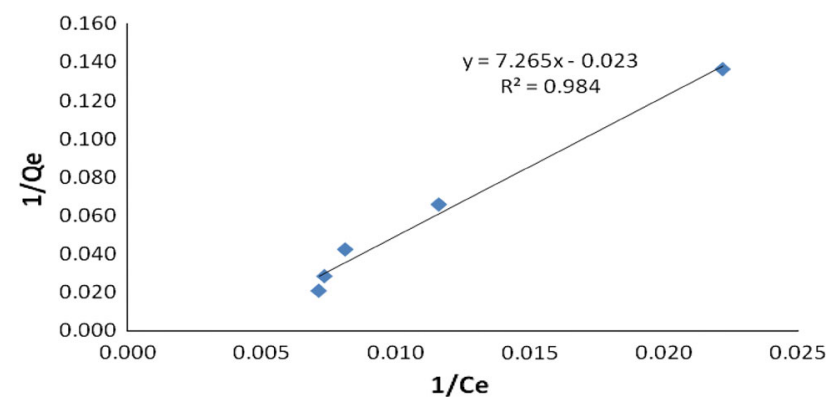

Fig. 6 Langmuir adsorption isotherm

affinity of the adsorbent. The experimental data for the uptake of cadmium ions were applied to both the Freundlich and Langmuir isotherm models as shown in Figs. 6 and 7 , respectively. The data fit well into both the isotherms. These Freundlich and Langmuir parameters compare well with those of other adsorbents that have been reported (Akar and Tunali 2006) The values of the parameters show that PPBM is a good adsorbent for the uptake of $\mathrm{Cd}(\mathrm{II})$ from aqueous solution.

The Langmuir expression is valid for monolayer adsorption onto a surface with finite number of identical sites (homogenous) without any interaction between adsorbed ions. The Langmuir expression or equilibrium ion removed is given by:

$\frac{1}{Q_{\mathrm{e}}}=\frac{1}{q b C_{\mathrm{e}}}+\frac{1}{q}$

where $Q_{\mathrm{e}}$ is $\mathrm{Cd}(\mathrm{II})$ ions concentration at equilibrium $(\mathrm{mg} / \mathrm{g}) ; q$, maximum metal uptake per unit mass of PPBM (mg/g) adsorption capacity; $b$, Langmuir constant $(L)$ related to energy of sorption; $C_{\mathrm{e}}$, concentration of $\mathrm{Cd}(\mathrm{II})$ ions in aqueous phase. $b$ reflects quantitatively the affinity between the PPBM and Cd (II) ions. The values of $q$ and $b$ are the characteristics of the Langmuir model. They can be determined by linearizing above equation.

$\frac{C_{\mathrm{e}}}{Q_{\mathrm{e}}}=\frac{1}{q b}+\frac{1}{q C_{\mathrm{e}}}$

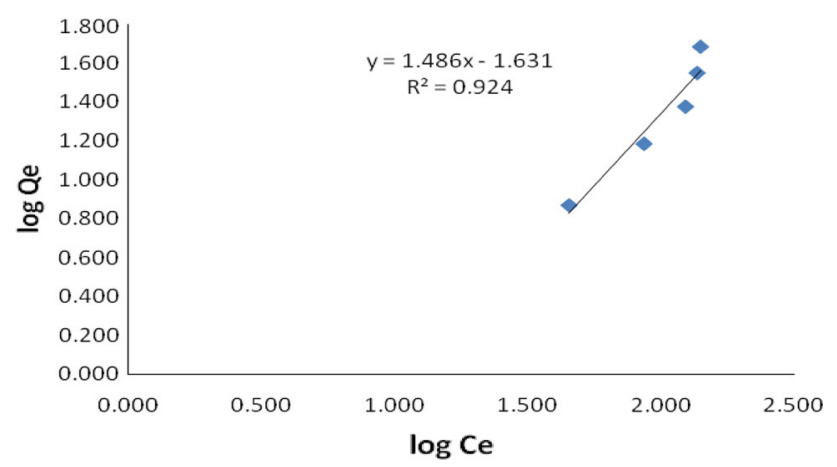

Fig. 7 Freundlich adsorption isotherm
A plot of $1 / Q_{\mathrm{e}}$ versus $1 / C_{\mathrm{e}}$ gives a straight line of slope $1 / q b$ and intercept $1 /(q)$. The value of $Q_{\mathrm{e}}$ is given from the following equation:

$Q_{\mathrm{e}}=\left(C_{\mathrm{i}}-C_{\mathrm{e}}\right) /(m / v)$

where $C_{\mathrm{i}}$ is the initial concentration of $\mathrm{Cd}(\mathrm{II})$ ions in the solution (mg/l); $C_{\mathrm{e}}$, concentration of $\mathrm{Cd}$ (II) ions at equilibrium; $v$, initial volume of $\mathrm{Cd}(\mathrm{II})$ ions solution used (1); $m$, mass of PPBM used $(\mathrm{g})$.

Figure 6 shows the compiled results for Langmuir isotherm. The result of regression analysis for calculating the parameters of Langmuir shows that $q$ is $43.480 \mathrm{mg} \mathrm{g}^{-1}$ and adsorption equilibrium constant is $0.0031 \mathrm{mg}^{-1}$.

The Freundlich expression is an empirical equation based on adsorption on a monolayer heterogeneous surface with interactions between adsorbed molecules and was used to estimate the adsorption capacity and intensity of metal ions towards the adsorbent.

Freundlich isotherm: $Q_{\mathrm{e}}=K C_{\mathrm{e}}^{1 / n}, K$ is the Freundlich constant indicating the adsorption capacity and $n$ is the Freundlich constant, indicating the adsorption intensity.

The above equation is rearranged in linear form to give: $\log Q_{\mathrm{e}}=\log K+1 / n \log C_{\mathrm{e}}$

where $K$ and $n$ were determined from the intercept and slope, respectively, from the plot of $\log Q_{\mathrm{e}}$ versus $\log C_{\mathrm{e}}$. Calculation from Freundlich equation, value of $K$ is $42.756 \mathrm{mg} / \mathrm{g}$ and value of $n$ is 0.673 . Results are represented in Fig. 7.

The coefficient of co-relation $\left(R^{2}\right)$ was found to be as high as 0.984 and 0.924 for Langmuir and Freundlich isotherm, respectively, for the adsorption of cadmium ions. These results showed that the equilibrium adsorption data conformed well to both the isotherms, however, higher

Table 1 Comparison of adsorption capacity of various adsorbents for $\mathrm{Cd}(\mathrm{II})$ ions

\begin{tabular}{lll}
\hline Adsorbent & $q\left(\mathrm{mg} \mathrm{g}^{-1}\right)$ & Reference \\
\hline $\begin{array}{l}\text { Rice husk } \\
\text { Sugarcane bagasse }\end{array}$ & 24.7 & $\begin{array}{l}\text { Ajmal et al. (2003) } \\
\text { Krishnan and Anirudhan } \\
(2003)\end{array}$ \\
Tree fern & 16.3 & $\begin{array}{l}\text { Hoa and Wang (2004) } \\
\text { Green coconut shell }\end{array}$ \\
Waste Chinese herb & 17.5 & Pino et al. (2006) \\
Olive cake & 65.4 & Al-Anber and Matouq (2008) \\
Exhausted olive cake & 7.32 & Elouear et al. (2008) \\
Micro-particles of dried & $11-28$ & Benhimaa et al. (2008) \\
plant & 14.29 & Tangjuank et al. (2009) \\
Cashew nut shell & 15.65 & Azouaoua et al. (2010) \\
Coffee grounds & 3.15 & Zein et al. (2010) \\
Mangosteen & 43.48 & \\
Present study & & \\
\hline
\end{tabular}


value of $R^{2}$ indicates Langmuir as more favorable model. The essential characteristic of Langmuir isotherm can be shown in terms of $R_{\mathrm{L}}$ (dimensionless separation parameter) which is indicative of isotherm shape that predicts whether an adsorption system is favorable or unfavorable. $R_{\mathrm{L}}$ is defined as (Webi and Chakravort 1974)

$R_{\mathrm{L}}=1 /\left(1+b C_{0}\right)$

where $b$ is Langmuir constant and $C_{0}$ is initial concentration of $\mathrm{Cd}(\mathrm{II})$ ion. The adsorption process as a function of $R_{\mathrm{L}}$ may be described as (Chakravarty et al. 2008) if $R_{\mathrm{L}}>1$ unfavorable, $R_{\mathrm{L}}=1$ linear condition, $0<R_{\mathrm{L}}<1$ favorable condition, $R_{\mathrm{L}}=0$ irreversible condition. $R_{\mathrm{L}}$ lies between 0 and 1 which is 0.429 indicates the favorable adsorption of $\mathrm{Cd}(\mathrm{II})$ ions. Table 1 shows the comparative adsorption capacity of various adsorbents.

\section{Conclusion}

From the present investigation, we can conclude that the low-cost natural adsorbent dried portulaca biomass PPBM was a true green adsorbent that can efficiently remove cadmium ions present in the aqueous solution. The removal $\%$ of the cadmium ions was dependent on the $\mathrm{pH}$, contact time, initial cadmium ion concentration and adsorbent dose. Results showed that adsorption was a pH-dependent process and the maximum adsorption occurs at $\mathrm{pH} 6$. Equilibrium was attained in $100 \mathrm{~min}$. Kinetic data were successfully described by a pseudo-second-order model. Adsorption isotherms were modeled using the Langmuir, Freundlich models. Based on the correlation coefficients, the Langmuir model adequately described the adsorption of Cd(II) under all examined conditions. All results showed that portulaca plant biomass is an attractive alternate lowcost adsorbent for removal of cadmium ion from aqueous solution. This new green material (PPBM) obtained from portulaca plant was found to be an effective, economical and environmentally friendly adsorbent for the removal of cadmium ions from aqueous solution and may potentially be used for removal of other heavy metal ions too.

Acknowledgments Authors are thankful to the management of MMH College, Ghaziabad, for providing infrastructure support.

\section{References}

Abdel-Ghani NT, Hegazy AK, El-Chaghaby GA (2009) Typha domingensis leaf powder for decontamination of aluminium, iron, zinc and lead: biosorption kinetics and equilibrium modeling. Int J Environ Sci Tech 6(2):243-248

Ajmal M, Rao RA, Anwar S, Ahmad J, Ahmad R (2003) Adsorption studies on rice husk: removal and recovery of $\mathrm{Cd}$ (II) from wastewater. Bioresour Tech 86:147-149. doi:10.1016/S09608524(02)00159-1

Akar T, Tunali S (2006) Biosorption characteristics of Aspergillus flavus biomass for removal of $\mathrm{Pb}$ (II) and $\mathrm{Cu}$ (II) ions from an aqueous solution. Bioresour Tech 97:1780-1789. doi:10.1016/ j.biortech.2005.09.009

Al-Anber ZA, Matouq MAD (2008) Batch adsorption of cadmium ions from aqueous solution by means of olive cake. J Hazard Mater 151(1):194-201. doi:10.1016/j.hazmat.2007.05.069

Alhluwalia SS, Goyal D (2005) Removal of heavy metals by waste tea leaves from aqueous solution. Eng Life Sci 5(2):158-162. doi:10.1002/elsc.200420066

Al-Subu MM (2002) The interaction effects of cypress (Cupressus sempervirens), cinchona (Eucalyptus longifolia) and pine (Pinus halepensis) leaves on their efficiencies for lead removal from aqueous solutions. Adv Env Res 6:569-576. doi:10.1016/ S1093-0191(01)00103-4

Azouaoua N, Sadaouia Z, Djaafri A, Mokaddema H (2010) Adsorption of cadmium from aqueous solution onto untreated coffee grounds: equilibrium, kinetics and thermodynamics. J Hazard Mater 184(1-3):126-134. doi:10.1016/j.hazmat.2010.08.014

Babarinde NAA, Babalola JO, Sanni SO (2007) Isotherm and thermodynamic studies of the biosorption of Cd(II) from solution by maize leaf. Int J Phys Sci 2(8):207-211

Benhimaa H, Chiban M, Sinan F, Seta P, Persin M (2008) Removal of lead and cadmium ions from aqueous solution by adsorption onto micro-particles of dry plants. Coll Surf B: Biointerfaces 61:10-16. doi:10.1016/j.colsurfb.2007.06.024

Brady D, Duncan JR (1994) Bioaccumulation of metal cations by Saccharomyces cerevisiae. Appl Microbiol Biotechnol 41:149-154. doi:10.1007/BF00166098

Brown PA, Gill SA, Allen SJ (2000) Metal removal from wastewater using peat. Water Res 34(16):3907-3916. doi:10.1016/S00431354(00)00152-4

Brown PA, Brown JM, Allen SJ (2001) The application of Kudzu as a medium for adsorption of heavy metals from dilute aqueous waste streams. Bioresour Tech 78:195-201. doi:10.1016/S09608524(400)00144

Cay S, Uyanik A, Ozasik A (2004) Single and binary component adsorption of copper(II) and cadmium(II) from aqueous solutions using tea-industry waste. Sep Purif Technol 38:273-280

Chakravarty S, Pimple S, Chaturvedi HT, Singh S, Gupta KK (2008) Removal of copper from aqueous solution using newspaper pulp as an adsorbent. J Hazard Mater 159(2-3):396-403. doi: 10.1016/j.hazmat.2008.02.030

Chandra SK, Kamala CT, Chary NS, Anjaneyulu Y (2003) Removal of heavy metals using a plant biomass with reference to environmental control. Int J Miner Proc 68(1-2):37-45

Cheremisinoff PN (1995) Handbook of water and wastewater treatment technology. Marcel Dekker Inc, New York

Cruz CCV, Da Costa ACA, Henriques CA, Luna AS (2004) Kinetic modeling and equilibrium studies during cadmium biosorption by dead Sargassum sp. Biomass Bioresour Tech 91(3):249-257. doi:10.1016/S0960-8524(03)00194-9

Deans JR, Dixon BG (1992) Uptake of $\mathrm{Pb}^{2+}$ and $\mathrm{Cu}^{2+}$ by novel biopolymers. Water Res 26(4):469-472. doi:10.1016/0043-1354 (92) $90047-8$

Drash GA (1993) Increase of cadmium body burden for this century. Sci Total Environ 67:75-89

Dubey A, Shiwani S (2012) Adsorption of Lead using a new green material obtained from Portulaca plant. Int $\mathrm{J}$ Environ Sci Technol 9(1):15-20. doi:10.1007/S13762-011-0012-8

Elouear Z, Bouzid J, Boujelben N, Feki M, Montiel A (2008) The use of exhausted olive cake ash (EOCA) as a low cost adsorbent for the removal of toxic metal ions from aqueous solutions. Fuel 87:2582-2589. doi:10.1016/j.fuel.2008.01.019 
Harbone JB (1998) Methods of extraction and isolation. In: Phytochemical methods. Chapman \& Hall, London, pp 60-66

Ho SY, Mckay G (1999) Pseudo-second order model for sorption process. Process Biochem 34:451-465

Hoa YS, Wang CC (2004) Pseudo-isotherms for the sorption of cadmium ion onto tree fern. Process Biochem 39(6):761-765

Horsfall MJ, Abia AA (2003) Sorption of Cd(II) and Zn(II) ions from aqueous solutions by cassava waste biomass (Manihot sculenta Cranz). Water Res 37(20):4913-4923

Kokate CK (1986) Practical pharmacognosy, 1st edn. Vallabh Prakashan, New Delhi, p 111

Krishnan KA, Anirudhan TS (2003) Removal of cadmium(II) from aqueous solutions by steam activated sulphurised carbon prepared from sugar-cane bagasse pith: kinetics and equilibrium studies. Water SA 29:147-156

Lagergren S, Vetenskapsakad SK (1898) About the theory of so called adsorption of soluble substance. Handlingar 24(4):1-39

Liu Y, Chang X, Guo Y, Meng S (2006) Biosorption and preconcentration of lead and cadmium on waste Chinese herb Pang Da Hai. J Hazard Mater B 135:389-394. doi:10.1016/j.jhazmat. 2005.11.078

Low KS, Lee CK, Liew SC (2000) Sorption of cadmium and lead from aqueous solutions by spent grain. Process Biochem 36(1-2):59-64

Manal F (2007) Biosorption of cadmium and lead by Phragmites australis L. biomass using factorial experiment design. Global J Biotech Biochem 2(1):10-20

McKay G (1996) Use of adsorbents for the removal of pollutants from wastewaters. CRC Press, Boca

MINAS Pollution Control Acts, Rules, Notification Issued There Under Central Pollution Control Board, Ministry of Environment and Forests, Government of India, New Delhi, Sept 2001

Naiya TK, Chowdhury P, Bhattacharya AK, Das SK (2009) Saw dust and neem bark as low-cost natural biosorbent for adsorptive removal of $\mathrm{Zn}(\mathrm{II})$ and $\mathrm{Cd}(\mathrm{II})$ ions from aqueous solutions. J Chem Eng 148:68-79. doi:10.1016/j.cej.2008.08.002

Netzer A, Hughes DE (1984) Adsorption of copper, lead and cobalt by activated carbon. Water Res 18(8):927-933. doi:10.1016/ 0043-1354(84)90241-0

Park GP, Tae WK, Myeoung YC, Ik KY (2007) Activated carbon containing alginate adsorbent for the simultaneous removal of heavy metals and toxic organics. Process Biochem 42:13711377

Pavasant P, Apiratikul R, Sungkhum V, Suthiparinyanont P, Wattanachira S, Marhaba TF (2006) Biosorption of $\mathrm{Cu}^{2+}, \mathrm{Cd}^{2+}, \mathrm{Pb}^{2+}$ and $\mathrm{Zn}^{2+}$ using dried marine green macroalga Caulerpa lentillifera. Bioresour Tech 97:2321-2329. doi:10.1016/ j.biortech.2005.10.032

Pehlivan E, Altun T, Parlayici S (2009) Utilization of barley straws as biosorbent for $\mathrm{Cu}^{2+}$ and $\mathrm{Pb}^{2+}$ ions. J Hazard Mater 164(2-3):982-986. doi:10.1016/j.jhazmat.2008.08.115
Pino GH, Mesquita LMS, Torem ML, Pinto GAS (2006) Biosorption of cadmium by green coconut shell powder. Miner Eng 19:380-387

Prasanna Kumar Y, King P, Prasad VSRK (2007) Adsorption of zinc from aqueous solution using marine green algae-Ulva fasciata sp. Chem Eng J 129:161-166. doi:10.1016/j.cej.2006.10.023

Reed BE, Arunachalam S, Thomas B (1994) Removal of lead and cadmium from aqueous waste streams using granular activated carbon (GAC) columns. Environ Prog 13(1):60-64

Sawalha MF, Peralta-Videa JR, Romeor-Gonzalez J, Gardea-Torresdey JL (2006) Biosorption of $\mathrm{Cd}(\mathrm{II}), \mathrm{Cr}(\mathrm{II})$, and $\mathrm{Cr}(\mathrm{VI})$ by Saltbush (Atriplex Carnescens) biomass: thermodynamic and isotherm studies. J Coll Interface Sci 300:100-104. doi: 10.1016/j.cis.2006.03.029

Sitting M (1991) Handbook of toxic \& hazardous chemicals and carcinogens, 3rd edn. Noyes Publications, Park Ridge

Tangjuank S, Insuk N, Tontrakoon J, Udeye V (2009) Adsorption of Lead(II) and Cadmium(II) ions from aqueous solutions by adsorption on activated carbon prepared from cashew nut shells. World Acad Sci Eng Technol 52:110-116

Thun MJ, Schnorr TM, Smith AB, Halperin WE, Lemen RA (1985) Mortality among a cohort of U.S. cadmium production workers-an update. J Natl Cancer Inst 74:325-333

Ulmanu M, Marañón E, Fernández Y, Castrillón L, Anger I, Dumitriu D (2003) Removal of copper and cadmium ions from diluted aqueous solutions by low cost and waste material adsorbents. Water Air Soil Pollut 142(1-4):357-373

Vander Leeden MC, Troise FL, Todd DK (1990) The water encyclopedia, 2nd edn. Lewis Publishers, Michigan

Volesky B (1992) Biosorption of heavy metals, vol 24. CRC Press, Boca Raton, pp 13-14

Wang J, Chen C (2006) Biosorption of heavy metals by Saccharomyces cerevisae: a review. Biotechnol Adv 24:427-451. doi: 10.1016/biotechadv.2006.03.001

Webi TW, Chakravort RK (1974) Pore and solid diffusion models for fixed bed adsorbents. J Am Inst Chem Eng 20(2):228-238

WHO (World Health Organization) (1971) International standards for drinking water, vol 3, 3rd edn. World Health Organization, Geneva. doi:10.1016/j.desal.2010.07.042

Witek-Krowiak A, Szafran RG, Modelski S (2011) Biosorption of heavy metals from aqueous solutions onto peanut shell as a lowcost biosorbent. Desalination 265:126-134. doi:10.1016/ j.desal.2010.07.042

Xiong C, Yao C, Wang L, Ke J (2009) Adsorption behavior of Cd(II) from aqueous solutions onto gel-type weak acid resin. Hydrometallurgy 98:318-324. doi:10.1016/j.hydramet.2009.05.008

Zein R, Suhaili R, Earnestly F, Indrawati, Munaf E (2010) Removal of $\mathrm{Pb}(\mathrm{II}), \mathrm{Cd}(\mathrm{II})$ and $\mathrm{Co}(\mathrm{II})$ from aqueous solution using Garcinia mangostana L. fruit shell. J Hazard Mater 181:52-56. doi:10.1016/j.hazmat.2010.04.076 